\title{
Contulma vascaina sp. n. (Insecta: Trichoptera: Anomalopsychidae), a new species from Rio de Janeiro state, southeastern Brazil
}

\author{
LEANDRO L. DUMAS
}

\begin{abstract}
Laboratório de Entomologia, Departamento de Zoologia, Instituto de Biologia, Universidade Federal do Rio de Janeiro,
\end{abstract} Avenida Carlos Chagas Filho, 373, Cidade Universitária, Ilha do Fundão, 21941-912 Rio de Janeiro, RJ, Brazil

Manuscript received on October 9, 2017; accepted for publication on March 7, 2018

\begin{abstract}
The caddisfly genus Contulma Flint, 1969, with 30 described species, is endemic to the Neotropics. In addition to the five species currently recorded from Brazil, a new species of Contulma is described and illustrated in this work. Contulma vascaina sp. n. is similar to C. sana Jardim and Nessimian, 2011 in prominent, slender and rod-like posterolateral lobe of segment IX, but the new species has a shorter posterolateral lobe, with long, spine-like seta apically. Contulma vascaina sp. n. can also be characterized by the presence of a large, hood-like sclerotized plate on the endothecal phallic membrane. The female genital structure is also described and illustrated.
\end{abstract}

Key words: Atlantic Forest, caddisfly, Contulma, female description, taxonomy.

\section{INTRODUCTION}

The endemic Neotropical family Anomalopsychidae was erected by Flint (1981) toinclude Anomalopsyche minuta (Schmid, 1957) and Contulma cranifer Flint, 1969, both from Chile and previously included in Sericostomatidae. Almost four decades later, the genus Anomalopsyche Flint, 1967 is still monotypic, but several species have been described in the genus Contulma Flint, 1969 (Holzenthal and Flint 1995, Holzenthal and Robertson 2006, Jardim and Nessimian 2011, Holzenthal and Ríos-Touma 2012, Holzenthal et al. 2017). Currently, the genus Contulma comprises 30 species described from Costa Rica, the Andes from Colombia to Chile, and mountainous areas of Southeastern Brazil (Holzenthal et al. 2017).

E-mail: 1ldumas82@gmail.com
Members of Contulma can be founded associated with first order small streams, especially in splash zones of waterfalls and seeps in lush and remote mountainous areas, as well as high elevation Andean páramo streams (Holzenthal and Flint 1995, Holzenthal and Ríos-Touma 2012). The species seem to display patterns of local endemism, being rarely attracted to light traps (Holzenthal and Robertson 2006). These particularities make it difficult to collect a large number of individuals. Most of the 30 species were described with few specimens (13 of them described based on a single male).

Holzenthal and Flint (1995) revised the genus and presented a species phylogeny based on morphological characters. Since that time only nine species have been described, but according to Holzenthal and Calor (2017) many more possible new species await discovery. Holzenthal et al. 
(2017) provided a key to the males of the 30 known species. The species of the genus can be mainly recognized by the pattern of wing venation and genitalic structure: forewing with Rs shorter than $\mathrm{R} 2+3$ or $\mathrm{R} 4+5$, crossvein of $\mathrm{M} 3+4$ joining $\mathrm{CuA}$ basally at fork and vein $1 \mathrm{~A}$ looping at $\mathrm{CuP}$ near its base; hind wing apparently lacks fork I; male genitalia with tergum $\mathrm{X}$ reduced and membranous, and inferior appendages small and highly modified; female with modified segment VIII, bearing a curved tergum and elongated, dorsally concave sternum (probably used to hold the egg mass), and genitalia with vaginal sclerites trident-shaped (Holzenthal and Flint 1995).

In Brazil, five species of Contulma are reported from southeastern mountainous areas of the country (Souza and Santos 2017). In the present work, a new species of Contulma is described and illustrated from specimens collected in Atlantic Forest areas in the Rio de Janeiro state, southeastern Brazil. The specimens were collected in three different altitudinal ranges $-160 \mathrm{~m}, 700 \mathrm{~m}$, and $1,110 \mathrm{~m}$, all of in which were second order streams inside wellpreserved protected areas.

The ZooBank Life Science Identifier (LSID) of this publication is: urn:lsid:zoobank. org:pub:3518412F-2213-427F-A71A-32B21C241BAA.

\section{MATERIALS AND METHODS}

Pennsylvania light traps (Frost 1957) and Malaise traps (Gressit and Gressit 1952) were used to capture adult specimens which were preserved in $96 \%$ ethanol. In order to observe genital structures, male abdomens were removed and cleared for identification using an $85 \%$ lactic acid solution heated to $125^{\circ} \mathrm{C}$ for 20 minutes, followed by a rinse in distilled water (Blahnik et al. 2007), and mounted temporarily in glycerin jelly (Pennak 1978) on a slide for viewing and drawing. Removed abdomens were stored permanently in micro vials with $96 \%$ ethanol. Genitalia were examined under a compound microscope (Carl Zeiss, Axio Lab) equipped with a camera lucida, and their diagnostic structures were drawn in pencil. Sketches were used as templates to trace graphic vectors in Adobe Illustrator CS6 (v. 16.0.0, Adobe Systems, Inc.). Morphological terminology followed Holzenthal and Flint (1995) and Holzenthal and Robertson (2006).

The specimens examined are deposited in the Coleção Entomológica Professor José Alfredo Pinheiro Dutra, Departamento de Zoologia, Universidade Federal do Rio de Janeiro, Rio de Janeiro, Brazil (DZRJ).

\section{TAXONOMY}

Contulma vascaina, NEW SPECIES

ZooBank Life Science Identifier (LSID) urn:1sid:zoobank.org:act:A9E59711-69FF-4B07B498-6A9383311E2D

Diagnosis. The new species resembles the other Brazilian species - Contulma fluminensis Holzenthal and Robertson, 2006, C. meloi Holzenthal and Robertson, 2006, C. sana Jardim and Nessimian, 2011, C. tijuca Holzenthal and Flint, 1995 and C. tripui Holzenthal and Robertson, 2006, sharing the general structure of posterolateral lobes and the dorsomesal processes (reduced or short in C. meloi) of male segment IX. However, C. vascaina sp. $\mathrm{n}$. is more similar to $C$. sana by the structure of segment IX, which has a prominent, slender and rod-like posterolateral lobe (large and rounded in the others species). It also differs in that the segment IX posterolateral lobe of $C$. vascaina $\mathrm{sp} . \mathrm{n}$. is shorter (half length of the height of segment IX) and has a long, spine-like seta at apex, while in C. sana it is longer (subequal in length to the height of segment IX) and has small setae at apex (Fig. 1, in Jardim and Nessimian 2011). Additionally, the new species has a large sclerotized plate on the endothecal phallic membrane, hood-like in dorsal and ventral view, different from sclerites of other species which posses this structure $-C$. 

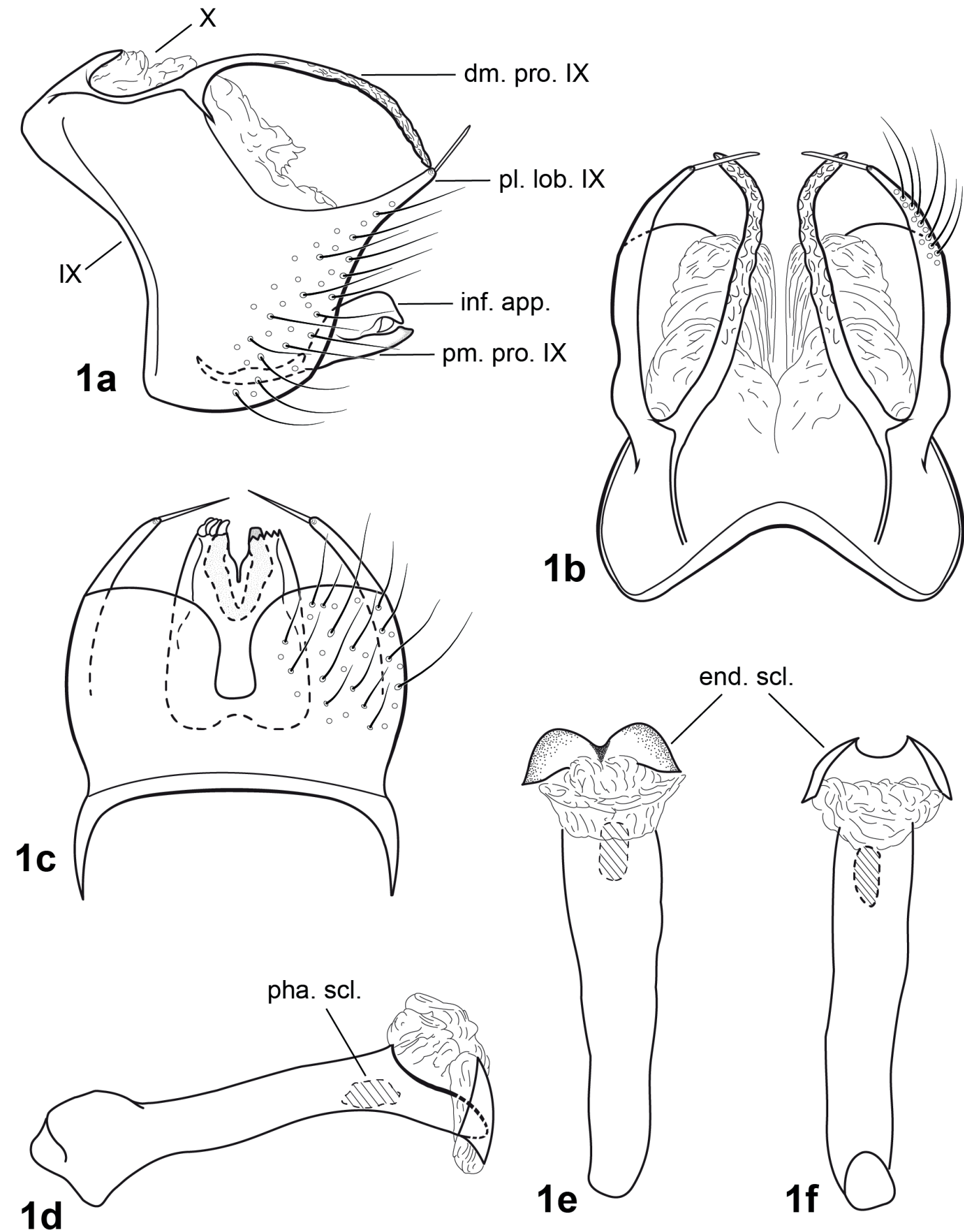

$\overline{0.1 \mathrm{~mm}}$

Figure 1 - Contulma vascaina sp. n., holotype male. 1a. Genitalia, left lateral; 1b. Genitalia, dorsal; 1c. Genitalia, ventral; 1d. Phallus, left lateral; 1e. Phallus, dorsal; 1f. Phallus, ventral. Abbreviations: IX - segment IX; X - tergum $\mathrm{X}$; dm. pro. IX - dorsomesal process of segment IX; pl. lob. IX - posterolateral lobe of segment IX; inf. app. - inferior appendage; pm. pro. IX - posteromesal process of segment IX; phs. scl. - phallic sclerite; end. scl. - endothecal sclerites. Scale: $0.1 \mathrm{~mm}$. 
fluminensis with many complex sclerites, C. tripui with complex hood-like sclerites, and C. tijuca with small paired triangular plates.

Description. Male: General color brown (in alcohol). Forewing length: 3.52-5.12 $\mathrm{mm}(\mathrm{n}=4$; holotype male $=4.48 \mathrm{~mm}$ ). Tibial spur formula $2,2,4$. Wings light brown, venation typical for the genus; forewing with forks I, II, III and V present, discoidal and thyridial cells short, subequal; hind wing with forks II and V present, R2, R3 and R4 fused till apex of the wing, discoidal cell not present.

Male genitalia: Segment IX, in lateral view (Fig. 1a), heavily setose posteroventrally; anterodorsal margin produced anteriorly, posterolateral margin strongly produced medially to form paired slender, rod-like posterolateral lobe, almost half the length of segment IX, each bearing a long, spine-like seta apically; posteriorly with paired, slender, rodlike dorsomesal process, curved ventrad, almost reaching lobe of posterolateral margin, apical half rugose, apex digitate; ventrally with posteromesal, sclerotized process; in dorsal view (Fig. 1b), tergum IX reduced, dorsomesal processes curved laterad apically; in ventral view (Fig. 1c), sternum IX subrectangular, with mesoapical large cleft extending slightly beyond halflength of the segment, forming two large, subquadrate lobes; posteromesal process with basal margin bearing a short concavity, apically V-shaped cleft, with anterolateral corners each bearing about 3-4 flat, closely apressed toothlike setae at apex; posterolateral lobes converging inward (Fig. 1c). Segment X entirely membranous, not reaching apex of dorsomesal lobes, formed by paired short dorsal lobes and paired long ventral lobes (Figs. 1a, b). Inferior appendages short, fused to base of posteromesal process of sternum IX, forming highly complex structure; in lateral view, subrectangular, dorsal margin straight, ventral margin concave near apex, truncate apically (Fig. 1a); in ventral view, U-shaped (Fig. 1c). Process of subphallic membrane not visible or absent.
Phallus complex; phallobase tubular, elongate, slender, and heavily sclerotized (Figs. 1d, f); apex of phallus with small dorsal membranous lobe and ventral sclerotized lip (Fig. 1d); phallicata reduced; endothecal membranes well developed, convoluted, bearing a huge sclerotized process apically positioned, subtriangular in lateral view (Fig. 1d), hood-like in dorsal and ventral views (Figs. 1e, 1f), in dorsal view, apparently covered with many microsetae (Fig. 1e); phallotremal sclerite subspherical (Figs. 1d, f).

Female: Color apparently as in male; forewing length: 5.28 - $5.44 \mathrm{~mm}(\mathrm{n}=3)$. Abdominal segments II-VIII heavily setose; sternite V with lightly sclerotized areas anterolaterally; sternum VIII broad, oblong, with slight mesoapical concavity, heavily setose (Fig. 2a); tergum IX widest at base, with ventral margin strongly concave, apical margin with V-shaped cleft, apex setose, anterolateral and basolateral surfaces with darkly pigmented areas (Fig. 2b). Vaginal apparatus, in ventral view, with base short, robust, narrowest medially; apex trident-shaped, with paired, slender, sclerotized midlateral processes, apically acute, single medial process longer and larger than midlateral processes, parallel-sided margins, strongly tapering near acute apex; apical membranes broad, highly convoluted, without sclerotized apical process (Fig. 2c).

Holotype male: BRAZIL: Rio de Janeiro: Nova Iguaçu, Tinguá, REBIO Tinguá, estrada de captação de água do Macuco, Rio Macuco, 22³4’42.4” S, 4326'03.4” W, 15.ix.2016, 163 m, LL Dumas, JL Nessimian and JF Barbosa leg. (DZRJ).

Paratypes: same data as holotype, 1 male, 2 females (DZRJ); Rio de Janeiro, Teresópolis, PN da Serra dos Órgãos, Rio Paquequer (ponte), 22॰27'25.5” S, 42॰59'51.8” W, 23-26.vii.2016, $1112 \mathrm{~m}$, ALH Oliveira, JLC Borges and JL Nessimian leg., 1 male, 1 female (DZRJ); Rio de Janeiro, Santa Maria Madalena, PE do Desengano, Rifa, Rio Rifa (estação de tratamento da CEDAE), 21'57'10.6” S, 41 '57'17.5” W, 15.iv.2016, 695 


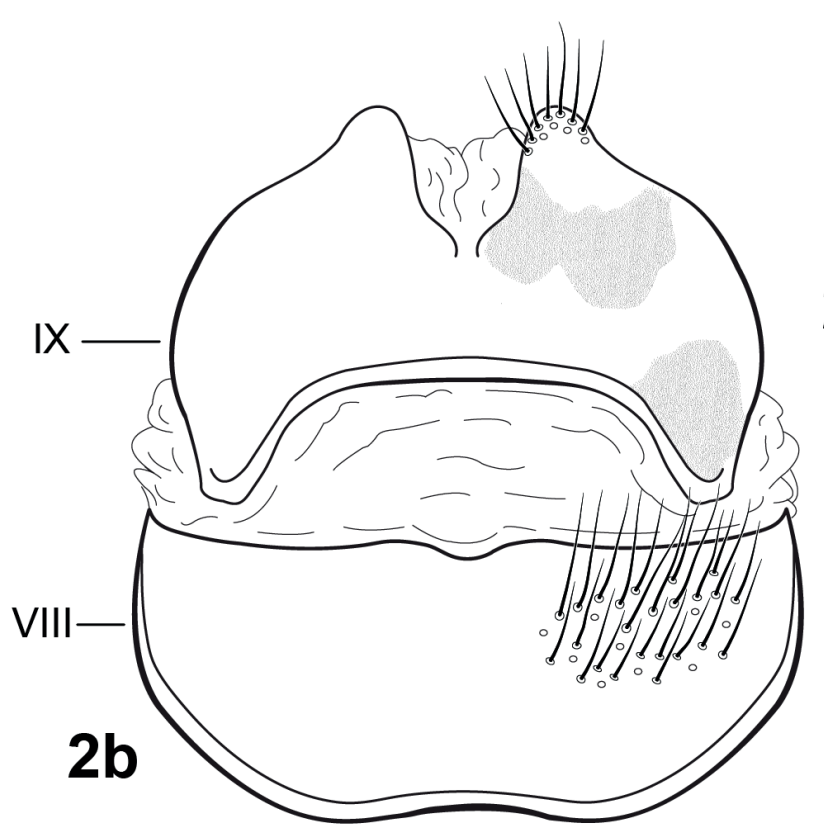

$\overline{0.1 \mathrm{~mm}}$
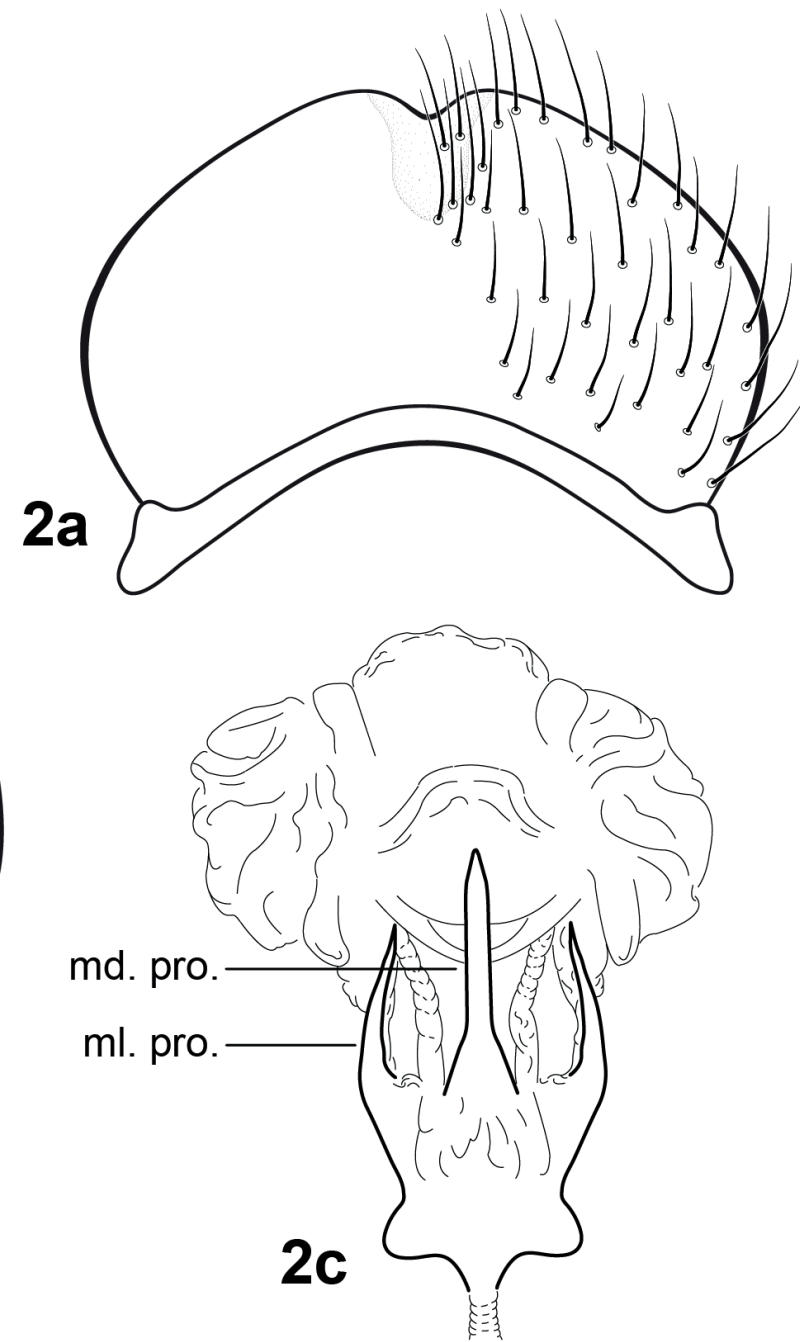

Figure 2 - Contulma vascaina sp. n., female genitalia. 2a. Sternum VIII, ventral; 2b. Apex of abdomen, dorsal; 2c. Vaginal apparatus, ventral. Abbreviations: VIII - tergum VIII; IX - tergum IX; md. pro. - medial process; ml. pro. - midlateral process. Scale: $0.1 \mathrm{~mm}$.

m, LL Dumas, JL Nessimian, CS Portela and JF Barbosa leg., 1 male (DZRJ).

Distribution: Brazil (RJ).

Etymology: The specific epithet is in honour of the traditional Club de Regatas Vasco da Gama, founded August 21, 1898. It is a century-old Brazilian sports club, especially soccer, located in Rio de Janeiro State, Brazil, of which the author is a huge supporter. Vasco da Gama is one of the most popular and successful clubs in Brazil, with more than 20 million supporters; its legions of fans are known as "vascaínos".

\section{ACKNOWLEDGMENTS}

I thank all members of Laboratório de Entomologia (UFRJ) that assisted with the collection of specimens and the teams of Reserva Biológica do Tinguá, Parque Nacional da Serra dos Órgãos, and Parque Estadual do Desengano for support during field works. I am grateful to Wagner Rafael de Souza for important tips in the use of Adobe Illustrator. I also thank ICMBio (permit $n^{\circ} 44785$ 2/2014) and INEA (permit $n^{\circ} 038 / 2014$ ) for issuing collecting permits. This study was partially funded by Fundação Carlos Chagas Filho de Amparo à 
Pesquisa do Estado do Rio de Janeiro (FAPERJ), Coordenação de Aperfeiçoamento de Pessoal de Nível Superior (CAPES) and Conselho Nacional de Desenvolvimento Científico e Tecnológico (CNPq).

\section{REFERENCES}

BLAHNIK RJ, HOLZENTHAL RW AND PRATHER AL. 2007. The lactic acid method for clearing Trichoptera genitalia. In: Bueno-Soria J, Barba-Álvarez R and Armitage B (Eds), Proceedings of the $12^{\text {th }}$ International Symposium on Trichoptera, Ohio: The Caddis Press, Columbus, Ohio, USA, p. 9-14.

FLINT OS. 1967. Studies of Neotropical Caddisflies II, Trichoptera collected by Prof. J. Illies in the Chilean subregion. Beitr Neotr Fauna 5: 45-68.

FLINT OS. 1969. Studies of Neotropical caddis flies, IX: new genera and species from the Chilean subregion. Proc Entomol Soc Wash 71: 497-514.

FLINT OS. 1981. Studies of Neotropical caddisflies, XXVII: Anomalopsychidae, a new family of Trichoptera. In: Moretti GP (Ed), Proceedings of the $3^{\text {rd }}$ International Symposium on Trichoptera, The Hague: Dr. W. Junk Publishers, p. 75-85.

FROST SW. 1957. The Pennsylvania insect light trap. J Econ Entomol 50: 287-292.

GRESSIT JL AND GRESSI MK. 1952. An improved malaise trap. Pac Insects 4(1): 87-90.
HOLZENTHAL RW AND CALOR AR. 2017. Catalog of the Neotropical Trichoptera (Caddisflies). Zookeys 654: $1-566$.

HOLZENTHAL RW AND FLINT OS. 1995. Studies of Neotropical caddisflies, LI: Systematics of the Neotropical caddisfly genus Contulma (Trichoptera: Anomalopsychidae). Smiths Contr Zool 575: 1-59.

HOLZENTHAL RW AND RÍOS-TOUMA B. 2012. Contulma paluguillensis (Trichoptera: Anomalopsychidae), a new caddisfly from the high Andes of Ecuador, and its natural history. Freshw Sci 31(2): 442-450.

HOLZENTHAL RW, RÍOS-TOUMA B AND RÁZURIGONZALES E. 2017. New species of the endemic Neotropical caddisfly genus Contulma from the Andes of Ecuador (Trichoptera: Anomalopsychidae). PeerJ 5: e3967.

HOLZENTHAL RW AND ROBERTSON DR. 2006. Four new species of Contulma from South America (Trichoptera: Anomalopsychidae). Zootaxa 355: 49-59.

JARDIM GA AND NESSIMIAN JL. 2011. A new species of Contulma Flint (Trichoptera, Anomalopsychidae) from southeastern Brazil. Rev Bras Entomol 55(2): 226-228.

PENNAK RW. 1978. Appendix B. Reagents and solutions. In: Pennak RW (Ed), Fresh-water invertebrates of the United States, United States: J Wiley \& Sons, Inc, p. 777-782.

SCHMID F. 1957. Contribution à l'étude des Trichoptères néotropicaux II. Beitr Entomol 7: 379-398.

SOUZA WRM AND SANTOS APM. 2017. Anomalopsychidae. In: Catálogo Taxonômico da Fauna do Brasil. PNUD. Disponível em: http://fauna.jbrj.gov.br/ fauna/faunadobrasil/18186. 